\title{
Peluang dan Tantangan Usaha Kecil Menengah (UKM) Berbasis Syariah Menghadapi Masyarakat Ekonomi Asean (MEA) di kota Pekanbaru
}

\author{
Nurlasera \& Qomariah L \\ Fakultas Eonomi dan Ilmu Sosial - Universitas Islam Negeri Sultan Syarif \\ Kasim Riau \\ nurlasera@uin-suska.ac.id / Qomariah.l@uin-suska.ac.id
}

\begin{abstract}
Abstrak
Penelitian ini bertujuan menganalisis secara kualitatif peluang dan tantangan Usaha Kecil Menengah (UMKM) yang mempunyai konsep syariah dalam menjalankan aktivitas usahanya pada tantangan Masyarakat Ekonomi Asean (MEA) di kota Pekanbaru. Dilihat dari aspek produk, semua bahan baku yang digunakan dalam produksi halal. Masalah kehalalan bahan baku ada juga responden yang belum mengetahui ada perbedaan halal yang dikeluarkan dari LPPOM MUI dan halal yang dikeluarkan sendiri oleh perusahaan. Dari aspek transaksi pelaku usaha berusaha secara syariah, jujur dengan produk yang dijual, berusaha menggunakan jasa perbankan syariah. Dari aspek pelaksanaan syariah oleh pelaku dan tim bisnisnya menerapkan ibadah-ibadah fardhu dan sunnah dengan baik, seperti sholat tepat waktu, menunaikan sholat dhuha, membaca alquran dan sebagainya.UMKM berbasis syariah mempunyai peluang dalam usaha di kota Pekanbaru bahkan bisa sampai ekspor ke luar negeri. Tantangan yang dihadapi UMKM syariah ini adalah pelaku UMKM syariah lain yang lebih kuat dan UMKM konvensional.
\end{abstract}

Keyword : UMKM, konsep syariah,MEA

\section{Pendahuluan}

Indonesia dan sembilan negara anggota ASEAN lainnya telah menyepakati perjanjian Masyarakat Ekonomi ASEAN (MEA) atau ASEAN Economic Community $(A E C)$. Tujuan yang ingin dicapai melalui MEA adalah adanya aliran bebas barang, jasa, dan tenaga kerja terlatih, serta aliran investasi yang lebih bebas. Dalam penerapanya pada 2015, MEA akan menerapkan 12 sektor prioritas yang disebut free flow of skilled labor (arus bebas tenaga kerja terampil). Ke-12 sektor terampil itu adalah untuk perawatan kesehatan (health care) turisme (tourism) jasa logistic (logistic services) e-ASEAN, jasa angkutan udara (air travel transport) produk berbasis agro (agro based products) barang-barang electronic (electronics), perikanan (fisheris), produk berbasis karet (rubber based products), tekstil dan pakaian (textiles and appareles), otomotif (otomotive) dan produk berbasis kayu (wood based products). (Yuni, 2015).

Salah satu indikator keberhasilan pembangunan adalah terjadinya pertumbuhan ekonomi. Peningkatan pembangunan ekonomi ini dapat dilihat dari Laju Pertumbuhan Ekonomi (LPE). Bersamaan dengan dengan terjadinya 
pertumbuhan ekonomi diharapkan berkurangnya angka kemiskinan dan pengangguran. Proses pertumbuhan ekonomi juga didukung oleh keberadaan Usaha Kecil Menengah (UKM), salah satu karakteristik utama yang dimilikinya yaitu merupakan usaha padat karya yang menyerap banyak tenaga kerja (Tambunan, 2012). Data dari Kementerian Koperasi dan UKM menunjukkan peningkatan jumlah UKM sebanding dengan peningkatan penyerapan tenaga kerja. Pertumbuhan jumlah unit usaha dan penyerapan tenaga kerja UKM di Indonesia. Adapun perkembangan UKM di kota Pekanbaru dapat dilihat dari tabel berikut ini:

Tabel 1

Perkembangan UKM kota Pekanbaru 2010 - 2014

\begin{tabular}{|c|c|c|}
\hline Tahun & Jumlah UKM (unit) & Perkembangan (\%) \\
\hline 2010 & 93.095 & 0 \\
\hline 2011 & 93.095 & 0,07 \\
\hline 2012 & 93.161 & 0 \\
\hline 2013 & 93.161 & 0 \\
\hline 2014 & 93.161 & \\
\hline
\end{tabular}

Sumber : http://galeri-kumkm.riau.go.id

Dari data di atas dapat dilihat jumlah UKM di kota Pekanbaru dari tahun 2010 sampai 2011 tidak mengalami perkembangan. Kemudian pada tahun 2012 mengalami peningkatan 0,07\%, tetapi sampai tahun 2014 jumlah UKM juga tidak mengalami perubahan. Berdasarkan sektor usaha UKM di kota Pekanbaru dapat dilihat pada tabel berikut :

Tabel 2

UKM berdasarkan Sektor di kota Pekanbaru tahun 2014

\begin{tabular}{|c|l|c|}
\hline No & \multicolumn{1}{|c|}{ Sektor } & Jumlah (unit) \\
\hline 1 & Pertanian & 14.292 \\
\hline 2 & Pertambangan \& Penggalian & 35 \\
\hline 3 & Industri Pengolahan & 1768 \\
\hline 4 & Listrik, Gas, Air Bersih & 70 \\
\hline 5 & Konstruksi & 807 \\
\hline 6 & Perdagangan, hotel \& restoran & 55.808 \\
\hline 7 & Angkutan, komunikasi & 6.431 \\
\hline 8 & Keuangan, sewa & 243 \\
\hline 9 & Jasa-jasa & 13.707 \\
\hline & \multicolumn{2}{|c|}{ Total } \\
\hline
\end{tabular}

Sumber : $\underline{\text { http://galeri-kumkm.riau.go.id }}$

Dari data di atas dapat kita lihat sektor yang paling banyak UKM nya di kota Pekanbaru adalah sektor perdagangan, hotel dan restoran sebanyak 55.808 UKM, disusul sektor pertanian sebanyak 14.292 dan jasa-jasa sebanyak 13.707. 
Sedangkan sektor yang paling sedikit UKM nya adalah pertambangan dan penggalian yaitu sebanyak 35 unit.

Karakteristik syariah dari usaha yang dilakukan oleh pelaku UMKM dalam penelitian ini :

\section{a. Produk}

Dalam penelitian ini $85 \%$ pelaku UMKM menyatakan bahwa produk yang dihasilkan dan semua bahan baku yang digunakan dalam produksi halal. Masalah kehalalan bahan baku ada juga responden yang belum mengetahui ada perbedaan halal yang dikeluarkan dari LPPOM MUI dan halal yang dikeluarkan sendiri oleh perusahaan. Misalnya bahan baku seperti margarin atau bahan tambahan makanan seperti pengembang roti yang dijual dalam kemasan ulang (curah), tetapi tidak ada informasi pada kemasannya, kandungannya, halalnya serta expired nya. Bagi usaha kuliner, yang mesti diperhatikan tidak saja halalnya, tetapi juga termasuk thoyyib. Artinya Bahan baku yang digunakan mesti diperhatikan kandungannya, apakah aman untuk dikonsumsi atau mengandung bahan yang berbahaya atau bisa merusak bagi manusia. Bisa jadi halal nya terpenuhi, tetapi thoyiib tidak, maka seharusnya tidak digunakan sebagai bahan baku. Label halal yang bisa kita terima adalah yang dikeluarkan oleh LPPOM MUI, bukanlah halal yang dikeluarkan sendiri oleh perusahaan, karena yang dikeluarkan oleh perusahaan belum dilakukan pengujian/pemeriksaan oleh lembaga yang dipercaya oleh pemerintah di Indonesia (LPPOM-MUI).

Selain itu peneliti juga menemukan pada kemasan produk salah satu usaha kuliner himbauan kepada konsumen untuk berdoa sebelum makan. Artinya ada upaya dari perusahaan meng"edukasi" masyarakat menjadi lebih baik dalam pengamalan nilai-nilai agamanya, terutama agama Islam.

\section{b. Transaksi}

Pelaku UMKM yang diteliti menyatakan 77,5\% transaksi dalam usaha yang dilakukan $60 \%$ sudah sesudah sesuai syari'ah. Dalam transaksi ini yang dimaksud peneliti antara lain pelaku usaha berusaha jujur dengan produk yang dijual, misalnya kondisi barang yang kurang baik jangan dikatakan baik, tidak mempermainkan takaran dan timbangan. Kesadaran tentang riba adalah sesuatu yang dilarang dan haram kami temukan pada para pelaku UMKM dan mereka berusaha keluar dari masalah riba tersebut. Dalam hal pemanfaatan jasa perbankan dalam transaksi, kesadaran menggunakan bank syariah sudah ada, tetapi ada yang masih menggunakan selain bank syariah juga bank konvensional karena kebutuhan, sebagai contoh salah satu pelaku usaha makanan yang kami teliti mengatakan :

"kami maunya semua transaksi menggunakan jasa perbankan syariah, tetapi ada salah satu mitra kita yang minta pembayarannya melalui bank konvensional, sampai saat ini masih kami penuhi dengan harapan suatu saat kami mempunyai daya tawar yang bisa lebih kuat dan mengarahkan mitra tersebut beralih dari bank konvensional ke bank syariah".

\section{c. Menerapkan nilai-nilai syariah dalam menjalankan usaha}


Pelaku UMKM yang kami teliti menyatakan bahwa $82,5 \%$ dari manajer dan karyawannya melaksanakan shalat fardhu awal waktu. Bahkan ada manajer yang menghukum karyawan yang lalai dalam sholat fardhu nya dalam bentuk lari keliling halaman tempat usahanya. Selain sholat fardhu, juga ada manajer yang mewajibkan karyawan untuk melaksanakan sholat sunnah dhuha. Responden sebagian besar menyadari kewajiban membayar zakat dari hasil usaha, terlihat dari jawaban responden, $80 \%$ sudah membayarkan zakatnya, 20\% yang belum membayarkan disebabkan belum sampai nisab dan haulnya. Selain membayarkan zakat, kesadaran responden terhadap membayarkan infak, sedekah juga baik, seluruh responden membayarkan infak/sedekah, tetapi ada yang rutin dan ada yang tidak rutin.

Dalam hal menjalankan usaha, para pelaku usaha berupaya menanamkan konsep/prinsip syariah menjadi hal yang penting. Pemilik/manajer usaha berharap karyawan juga menerapkan dan melaksanakan hal-hal yang diperintahkan dalam syariah Islam dalam aktivitas/pekerjaan mereka. Sebagai contoh, pelaksanaan sholat lima waktu yang wajib dilakukan oleh setiap umat Islam yang sudah baligh. Perusahaan harus menyediakan tempat sholat/musholla yang layak $(67,5 \%)$ dari responden menyatakan sudah merealisasikannya). Sebagai pemilik atau manajer usaha dalam menjalankan usahanya $87,5 \%$ memberikan contoh/teladan bagi karyawannya dalam hal berbicara, bersikap dan berperilaku sehingga apa yang diharapkan oleh pemilik atau manajer terhadap karyawannya tidak hanya sekedar perintah atau aturan saja, tetapi diiringi dengan contoh nyata yang bisa ditiru oleh karyawan. Sebagai contoh manajer/pemilik yang ingin karyawannya melaksanakan sholat fardhu awal waktu dengan memberikan contoh kepada karyawan bisa mendorong karyawan melakukan hal yang sama. Supaya memberikan pemahaman pengamalan syariat Islam kepada karyawan, 25\% pelaku UMKM yang kami teliti mengadakan pengajian secara rutin, ada yang sekali setiap pekan, sekali dalam dua pekan.

Pimpinan atau manajer juga cukup tegas melarang dan menegur karyawan jika ada yang berbuat tidak sesuai dengan syariah Islam ( $85 \%$ dari hasil penelitian ini), misalnya ada karyawan yang belum belum melaksanakan sholat fardhu bahkan sholat sunnah dhuha dan diketahui oleh pimpinannya, pimpinan menegur dan mengingatkannya. Ada juga kebijakan salah satu pelaku usaha kuliner dalam penelitian ini yang memberikan reward bagi karyawan yang hafal Qur'an, mulai dari 1 juz dan seterusnya. Kemudian juga ada himbauan bagi karyawan untuk melakukan puasa sunnah.

\section{Upaya menjalankan usaha secara syari'ah}

Upaya yang dilakukan dalam menjalankan usaha secara syari'ah, responden pada umumnya berupaya melakukan peningkatan dengan berbagai cara. Mereka memberikan respon yang beragam. Banyak pelaku UMKM Syariah yang melaksanakan usaha syariahnya dengan mengikuti pelatihan-pelatihan yang terkait usaha syariah. Ada yang mengikuti pelatihan keuangan syariah melalui perbankan syariah, mengikuti pendidikan dan pelatihan jual beli syariah. Ada juga yang mengikuti pelatihan bisnis anti riba. Pelatihan e-commerce berbasis syariah, melakukan training dengan coach Ari Ginanjar tentang syariah. Pemilik sangat antusias dengan informasi-informasi yang beredar bahkan mereka membeli buku- 
buku seputar usaha syariah. Selain tiu juga memperbanyak bacaan tentang hukum hukum islam.

Selain mengikuti berbagai pelatihan dan membaca beragam buku syariah, Ada juga yang mencari informasi sebanyak-banyaknya melalui internet dan melalui media sosial. Saat ini media sosial menjadi trend untuk menyebarkan informasi ataupun hanya sekedar untuk aktualisasi diri. Media sosial tidak hanya menyebarkan informasi yang benar tetapi juga berita "hoax". Bagi pelaku UMKM Syariah yang kreatif, mereka harus memilah informasi yang didapat. Mengikuti perkembangan kafe-kafe yang ada di Pekanbaru dan mengikuti berbagai ajang/ even untuk mengangkat nama usaha, Menetapkan konsultan syariah dan bekerjasama dengan lembaga keuangan syariah dalam transaksi berbelanja, seminar busana muslim fashion sertifikasi karyawan Dinas Pariswisata Riau.

Informasi dari pelaku usaha juga mereka menciptakan makanan yang penuh dengan kreatifitas dan mengikuti perkembangan produk-produk halal. Mencobakan berbagai resep sehingga menemukan citra rasa terbaik dari berrbagai uji coba. Melihat perkembangan melalui media sosial mengenai makanan unik, sehat, dan halal. Terkait dengan usaha fashion, pelaku usaha berkreasi dengan desain baju muslimah, menambah pengetahuan busana syariah serta mengikuti berbagai kegiatan pameran dan fashion syariah.

\section{Tantangan Usaha Kecil Menengah (UKM) dalam Era Masyarakat Ekonomi Asean (MEA)}

Dengan gerakan ekonomi syariah (Gres), Indonesia berpeluang besar menjadi kekuatan ekonomi baru di ASEAN dan dunia. Betapa tidak, sebanyak 207.176.162 jiwa penduduk Indonesia yang beragama Islam (data sensus penduduk Badan Pusat Statistik 2010), bisa menjadi pondasi kekuatan ekonomi syariah di Indonesia. Belum lagi tingginya pertumbuhan perbankan syariah di Indonesia. Dilihat dari fenomena penduduk yang beragama Islam belakangan ini, terjadi peningkatan kesadaran tentang Islam dan berIslam lebi baik. Salah satu momentumnya adalah gerakan 212 pada tahun 2016.

Menurut Azwar dalam tulisannya Industri Perbankan Syariah Menghadapi Masyarakat Ekonomi Asean MEA 2015 Peluang dan Tantangan : Menghadapi MEA, di satu sisi masyarakat ASEAN seharusnya bergembira. Betapa tidak, MEA diharapkan dapat menciptakan komunitas regional yang diproyeksikan dapat menjaga stabilitas politik dan keamanan regional ASEAN, meningkatkan daya saing kawasan secara keseluruhan di pasar dunia, mendorong pertumbuhan ekonomi kawasan, mengurangi kemiskinan dan meningkatkan standar hidup penduduk negara anggota ASEAN.

Di sisi lain, kita juga harus mengakui bahwa MEA dapat menjadi salah satu jalan berkembangnya budaya homo economi lupus, dimana yang kuat memangsa yang lemah. Bayangkan, negara ASEAN adalah negara yang majemuk dari segi kemajuannya. Data perekonomian negara-negara ASEAN tahun 2010 yang diukur dari besarnya Gross Domestic Product (GDP) perkapita menunjukkan kesenjangan (gap) yang begitu besar antara the highest dan the lowest. Singapura sebagai negara maju di kawasan ASEAN memiliki pendapatan perkapita sebesar US\$ 53.180. 
Sedangkan Myanmar sebagai juru kunci hanya memiliki pendapatan perkapita sebesar US\$468,6. Pendapatan penduduk Myanmar tidak mencapai $1 \%$ pendapatan penduduk Singapura. Dengan kondisi seperti ini, negara seperti Myanmar tersebut bisa menjadi mangsa Singapura. GDP Indonesia mencapai US\$3.010,1 di tahun 2010 dan US\$3.542,9 di tahun 2011. Angka hanya 5,66 \% dari GDP Singapura. Namun perlu juga diingat bahwa di ASEAN Indonesia menyumbang $40 \%$ pasar bagi barang dan jasa yang diperdagangkan. Indonesia sebagai salah satu bagian dalam integrasi MEA tentu harus bersiap menghadapi era bebas tanpa batas ala MEA ini. Perekonomian Indonesia secara nasional diharapkan dapat terus tumbuh dengan baik untuk menunjang persaingan (competitiveness) di kawasan ASEAN. Indonesia sebagai salah satu bagian dalam integrasi MEA tentu harus bersiap menghadapi era bebas tanpa batas ala MEA ini. Perekonomian Indonesia secara nasional diharapkan dapat terus tumbuh dengan baik untuk menunjang persaingan (competitiveness) di kawasan ASEAN. Industri ekonomi dan perbankan syariah sebagai bagian struktur perekonomian bangsa Indonesia juga tidak lepas dari tuntutan. Namun, realita yang ada adalah bahwa sebagian pihak masih mengkhawatirkan hadirnya MEA sebagai sebuah ancaman karena pasar potensial domestik akan diambil oleh pesaing dari negara lain. Padahal, Kekhawatiran tersebut sesungguhnya tidak beralasan jika memang kita mampu menunjukkan daya saing (competitiveness) yang tinggi. Sebagai negara dengan penduduk muslim terbesar, sudah selayaknya Indonesia menjadi pelopor dan kiblat pengembangan industri dan keuangan syariah di ASEAN bahkan dunia. Hal ini bukan merupakan 'impian yang mustahil' karena potensi Indonesia untuk menjadi global player keuangan syariah sangatlah besar. Sehingga Indonesia melalui industri keuangan dan perbankan syariahnya akan mampu bersaing dalam kancah MEA. Meskipun tentu saja diakui bahwa di balik peluang dan kondisi yang dapat mendorong hal ini, juga terdapat ancaman-ancaman yang justru dapat menghambat perkembangan dan penguatan industri keuangan dan perbankan syariah sebagai salah satu pilar penyokong perekonomian bangsa Indonesia. MEA pun akan dijadikan sebagai kawasan yang memiliki perkembangan ekonomi yang merata, dengan memprioritaskan pada Usaha Kecil Menengah (UKM).

Kemampuan daya saing dan dinamisme UKM akan ditingkatkan dengan memfasilitasi akses mereka terhadap informasi terkini, kondisi pasar, pengembangan sumber daya manusia dalam hal peningkatan kemampuan, keuangan, serta teknologi. Tulisan tentang UKM berbasis syariah belum banyak ditemukan. Era kebangkitan umat Islam yang ditandai dengan maraknya kajian keIslaman di masjid, termasuk tema yang dibahas adalah tentang muamalah, bagaimana bertransaki yang sesuai dengan ajaran Islam. Hal yang menarik dibahas bagaimana pelaku UKM berbasis syariah menghadapi tantangan MEA.

Beberapa yang bisa dijadikan sebagai indikator UKM berbasis syariah adalah output yang dihasilkan halal, ditandai dengan adanya label halal dari LPPOM MUI, adanya perhatian khusus terhadap ibadah pada saat jam kerja (tidak boleh lalai dalam sholat), sumber pendanaan usaha lebih hati-hati dengan menghindari riba, menghindari adanya maisir, gharar dalam usaha. Pelaku usaha harus tahu tentang label halal, tidak cukup dengan pernyataan sendiri (self claim) 
bahwa produk yang mereka hasilkan adalah halal. Akan tetapi herus melalui pengakuan dan pengujian lembaga yang diakui oleh negara, yaitu LPPOM MUI.

Dalam hal transaksi syariah Allah telah memberikan rambu-rambu dalam Al-Quran antara lain :

1.

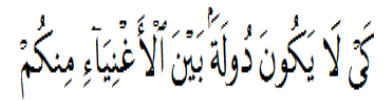

QS. 59/Al-Hashr ayat 7 :

Artinya : “... supaya harta itu jangan beredar diantara orang-orang kaya saja diantara kamu."

2. QS. 57/Al-Hadid ayat 7 :

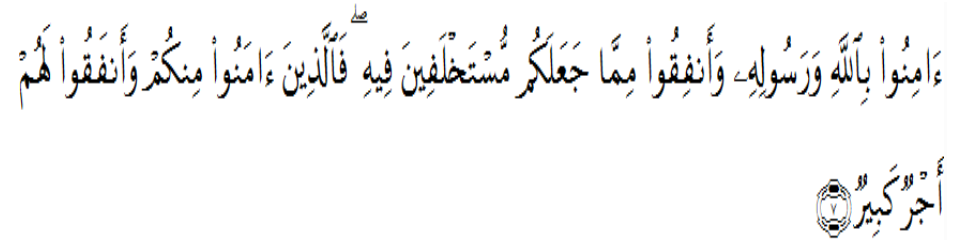

Artinya : “... berimanlah kamu kepada Allah dan Rasul-Nya dan nafkahkanlah sebagian dari hartamu yang Allah telah menjadikan kamu menguasainya. Maka orang-orang yang beriman di antara kamu dan menafkahkan (sebagian) dari hartanya memperoleh pahala yang besar."

3. QS. An-Nisa ayat 29 artinya : "Hai orang-orang yang beriman, janganlah kamu memakan harta sesamamu dengan jalan bathil"

4. QS. Al-Baqarah ayat 275 artinya : "Keadaan mereka yang demikian itu, adalah disebabkan mereka berkata (berpendapat), sesungguhnya Jual Beli itu sama dengan Riba, padahal Allah telah menghalalkan Jual Beli dan mengharamkan Riba ..."

Dalam hadis Rasulullah SAW bersabda artinya:

Riba itu mempunyai 72 pintu, dan yang paling rendah dosanya, seperti seseorang menyetubuhi ibunya ...(H.R. Thabrani)

Kemudian hadits yang diriwayatkan Imam Ahmad berikut ini tentang hubungan kerjasama dan hubungan timbal balik dari atribut modal sosial yang artinya : "Seorang hamba tidak mencapai hakikat iman hingga ia mencintai kebaikan untuk manusia seperti yang ia cintai untuk dirinya."

Informasi mengenai MEA bisa diperoleh melalui berbagai sarana dan media sosial. Tetapi persoalannya adalah sejauh mana masyarakat memahami implementasinya. Ada masyarakat yang tidak mengetahui sama sekali tentang MEA. Bahkan masyarakat yang mengetahui bahwa MEA berlaku pada tahun 2016 hanya 34,7\%, dan 65,3\% tidak tahu persis kapan MEA berlaku (Nurlasera, 2016).

Pelaku usaha yang optimis berpendapat bahwa dengan berlakunya MEA ini menjadi motivasi untuk meningkatkan kualitas produk dan pelayanan supaya sehingga bisa bersaing di perdagangan bebas, peluang bisnis dengan pihak asing menjadi lebih terbuka dan membuka kesempatan bermitra dengan luar negeri. 
Secara makro hal ini akan meningkatkan perekonomian negara. Sementara ada masyarakat yang pesimis dan ragu dikarenakan pelaku UKM masih memiliki keterbatasan modal dalam pengembangan usaha, keterbatasan akses mendapatkan pinjaman modal, keterbatasan kemampuan bahasa asing dan alasan lainnya.

Hasil survey juga menginformasikan bahwa Pelaku UKM mengeluhkan, sejauh ini pemerintah belum membuat kebijakan atau regulasi yang berpihak kepada perlindungan usaha bagi UKM. Regulasi yang ada saat ini, sifatnya masih pengawasan terhadap peredaran barang impor. Jika makanan tidak memenuhi standar, Disperindag langsung menarik dan menyita makanan tersebut. Kode ML itu dibuat di luar negeri, sementara MD dalam negeri yang diatur dalam tata niaga.

Kementerian Koperasi dan Usaha Kecil Menengah menyebutkan bahwa UMKM mampu menyerap 99,45\% tenaga kerja di Indonesia dengan asumsi dukungan perkembangan wirausaha sebanyak 6.67 juta dalam lima tahun. Dari prediksi tersebut, nampaknya usaha kecil diharapkan mampu memberikan lapangan kerja baru. Adanya lapangan kerja dan meningkatnya pendapatan diharapkan akan membantu mewujudkan masyarakat yang sejahtera.

Penelitian Hamdi tentang MEA bagi perbankan Syariah menyatakan bahwa Perbankan syariah Indonesia dapat dijadikan kekuatan negara Indonesia dalam menghadapi persaingan global Masyarakat Ekonomi ASEAN (MEA). Perbankan syariah Indonesia yang terbukti mampu bertahan dari krisis ekonomi global tahun 2008 telah terbukti memiliki kinerja yang baik dan diharapkan mampu menghadapi persaingan Masyarakat Ekonomi ASEAN (MEA). Industri keuangan syariah selama tahun 2013 masih tetap menunjukkan kinerja yang cukup baik, dan hal ini menjadi peluang besar bagi perbankan syariah Indonesia untuk dapat turut bersaing di era Masyarakat Ekonomi ASEAN (MEA). Hal yang sama juga diharapkan terjadi pada Usaha Kecil Menengah (UKM) berbasis syariah.

Meskipun tantangan yang dihadapi semakin berat, pelaku usaha harus optimis dan yakin bahwa usaha yang dikelola dengan prinsip syariah akan membawa ketenangan dan keberkahan disamping tentunya manfaat untuk duniawi. Adanya semangat spiritual secara berjama' ah dalam menjalankan usaha setidaknya sedikit demi sedikit akan dapat mengimbangi kekuatan ekonomi yang ada saat ini dan secara makro akan meningkatkan pendapatan nasional.

Dalam menjalankan usaha agar sesuai prinsip syariah, pelaku UKM bisa melalui :

a. Mengikuti traning, seminar, pelatihan.

b. Menggunakan jasa konsultan syariah.

c. Informasi dari media massa dan media sosial.

d. Mengikuti standarisasi dinas terkait

e. Pelatihan

f. Seminar

g. Mengikuti Kajian ke-Islaman di masjid, komunitas, dsb

h. Mengikuti standarisasi dari dinas terkait

i. Browsing, media sosial

j. Konsultan syariah

\section{Penutup}


Era Masyarakat Ekonomi Asean (MEA) tidak dapat dihindari. Setiap pelaku usaha siap atau tidak mesti menjalaninya. Semakin besar tantangan yang dihadapi, semakin kuat ikhtiar dan do'a pelaku usaha dalam beraktivitas. Ada keyakinan yang dalam bagi pelaku UKM berbasis syari'ah bahwa usaha yang dijalankan sebaik apapun tidak lepas dari campur tangan Allah SWT. Sehebat dan secanggih apapun sistem yang digunakan tidak akan bisa menghasilkan ouput yang baik jika tidak atas izin dari-Nya.

Penerapan prinsip syariah harus didukung oleh seluruh elemen yang ada dalam UKM, tidak hanya oleh pemilik atau manajer. Pemimpin atau manajer memberikan contoh kepada karyawan sehingga aturan yang dibuat terkait tentang prinsip syariah dalam menjalankan usaha menjadi sesuatu yang didukung secara bersama-sama.

Secara aturan atau undang-undang, pemerintah sebaiknya membuat regulasi yang lebih pro pada UKM yang ada di Indonesia sehingga pelaku usaha optimis untuk melanjutkan usaha mereka, termasuk pelaku usaha berbasis syariah.

\section{DAFTAR PUSTAKA}

Al-Quran

Alfin Samir \& Dwi Larso, Identifikasi Faktor-Faktor yang Mempengaruhi Kinerja UKM Catering di Kota Bandung, Jurnal Manajemen Teknologi, Volume 10 Number 2 Tahun 2011.

Anonim, http://www.cekau.com, tanggal Akses 13 April 2015.

Anonim, http://id.wikipedia.org/, tanggal akses 11 April 2015.

Azwar, Industri Perbankan Syariah Menghadapi Masyarakat Ekonomi Asean (MEA) 2015 : Peluang dan Tantangan Kontemporer, http://www.bppk.kemenkeu.go.id, tanggal akses 15 maret 2016.

Badan Pusat Statistik, Riau Dalam Angka 2014.

Bappenas, http://www.bappenas.go.id/ tanggal akses 11 April 2015

Dhika Putri Awwallin. (2014). Peluang, tantangan dan prospek perbankan syariah Indonesia dalam menghadapi persaingan masyarkat ekonomi ASEAN (MEA) 2015, Universitas Negeri Surabaya. www.google.com

Hamdi Agustin dkk, 2015, Tantangan dan peluang perbankan syariah dalam menghadapi Masyarakat Ekonomi ASEAN (MEA) 2015, Jurnal Ekonomi, Manajemen dan Akutansi I Vol. 25 No. 2 Desember 2015

Kementrian Negara Koperasi dan Usaha Kecil Menengah. LPDB-KUMKM

Kesi Widjajanti, 2011, MODEL PEMBERDAYAAN MASYARAKAT, Jurnal Ekonomi Pembangunan, Volume 12, Nomor 1, Juni 2011, hlm.15-27

Leavitt, Jacqueline dan Susan Saegert. 1990. "From Abandonment to Hope: Community Households in Harlem". New York: Columbia University Press.

Mas Irba H Sulaiman, Kota Pekanbaru Siapkan Aturan Sambut MEA, http://datariau.com/read-12-6257-2016-01-06-, tanggal akses 15 maret 2016.

Muhtadi Ahmad, Peran Lembaga Perekonomian Nahdlatul Ulama (LPNU) Dalam Perkembangan UMKM Berbasis Syariah, Jurnal Al-Iqtishad: Vol. II, No. 1, Januari 2010. 
Muliaman D Hadad, Industri Keuangan Syariah Menghadapi MEA, http://www2.jawapos.com, tanggal akses 15 maret 2016

Samsul Arifin, dkk, 2015, Masyarakat Ekonomi Asean 2015 Memperkuat Sinergi Asean Di Tengah Kompetisi Global (Jakarta:Bank Indonesia), hlm. 9

Undang-Undang No 21 Tahun 2008 tentang Perbankan Syariah.

Yuni, 2016, Makalah Peranan Perbankan dalam menghadapi Pasar bebas Asean, http://yunaynay.blogspot.co.id/2015/03/makalah-peranan-perbankandalam.html (25 Maret 2016) 